\title{
Arendt's Children in the Bahamian Context: The Children of Migrants Without Status
}

\author{
Kristy A. Belton ${ }^{1}$ \\ University of Connecticut
}

\begin{abstract}
In this increasingly globalized world, with hundreds of millions of people living outside the country of their birth, and States guarding their sovereign right to control membership ever more closely, the number of children without secure citizenship status is on the rise. This article is a case study of noncitizen children in The Bahamas, focusing specifically on children born of Haitian parents without status, "Arendt's children". It examines how The Bahamas, a State party to the United Nations Convention on the Rights of the Child (CRC), fails to consider adequately the best interests of the Bahamian-born non-citizen child in its laws and policies. It analyses how The Bahamas' ratification of relevant human rights treaties translates into practice at the domestic level and concludes with an examination of ways in which Arendt's children might be integrated into the Bahamian polity.
\end{abstract}

\section{INTRODUCTION}

"If you're illegal, you should not be able to produce a person who becomes legal when they are born here.” (Anonymous interviewee, 2009)

Writing in response to the atrocities of World War II, Hannah Arendt (1948/2004) spoke of the stark nakedness that results when one is no longer recognized as a member of any political community: "The Rights of Man, supposedly inalienable, proved to be unenforceable ... whenever people appeared who were no longer citizens of any sovereign state” (p. 372). Although some contest the importance of citizenship in this post-national era (Benhabib, 2004; Ong, 2006; Sassen, 2003; Soysal, 1998), the enjoyment of basic rights is often very difficult to achieve unless one is a citizen of somewhere. Children, who are often deemed "citizens-in-the- making” or not fully citizens because they cannot yet fulfil the traditional citizenship duties of voting or running for office, are often in a particularly vulnerable position when it comes to making demands for the fulfilment of their basic rights. Non-citizen children are in an even more precarious situation: they are "Arendt's Children" (Bhabha, 2009a).

Bhabha argues that Arendt's children:

do not in fact (regardless of whether they do in law) have a country to call their own because they are either noncitizens or children of noncitizens ... citizen or migrant children living in so-called 'mixed status' or 'undocumented' families, and unregistered or stateless children living in the country of their birth with their immigrant parents (p. 413).

In this increasingly globalized world, with

\footnotetext{
${ }^{1}$ Kristy A. Belton, Ph.D. student, Department of Political Science, University of Connecticut, Storrs, CT. She is the Managing Editor of the International Studies Review.

Acknowledgments: The author would like to thank all the interviewees who gave of their time and graciously answered her questions regarding statelessness in The Bahamas during the Summer of 2009. E-mail: kristy.belton@uconn.edu How to cite this article in APA (7th ed.) style: Belton, K. A. (2010). Arendt's children in the Bahamian context: The children of migrants without status. The International Journal of Bahamian Studies, 16, 3550. https://doi.org/10.15362/ijbs.v16i0.127
} 
hundreds of millions of people living outside of the country of their birth (International Organization for Migration, 2010), and States guarding their sovereign right to control membership ever more closely, the number of Arendt's children is on the rise (Bhabha, 2009a, p. 411). These children face exploitation, discrimination, and myriad human rights violations due to their special type of non-citizen status.

This article is a case study of non-citizen children in The Bahamas, focusing specifically on children born of Haitian parents without status in the country. ${ }^{2}$ Although no official count of the number of Bahamian-born children of parents without status exists, ${ }^{3}$ tens of thousands of undocumented Haitians are estimated to live in The Bahamas (Smith, 2008; U.S. Department of State, 2009), making this group of Arendt's children a potentially important percentage of the Bahamian population. The article examines how The Bahamas, a State party to the United Nations Convention on the Rights of the Child (CRC), fails to consider adequately the "best interests" of these children in its laws and policies. Section I provides the research rationale, describes how statelessness affects many of these children, and explains why this is such an important issue. Section II discusses The Bahamas' ratification of relevant international treaties pertaining to noncitizen children and how ratification of these treaties translates into practice at the domestic level. The final section concludes with an examination of ways in which Arendt's children might be integrated into the Bahamian polity.

\section{RESEARCH CONTEXT}

According to Southwick and Lynch (2009), statelessness is a problem in The Bahamas (p. 32),

\footnotetext{
${ }^{2}$ To be "without status" means that a person is undocumented or lacks an official invitation to reside in the Bahamas.

${ }^{3}$ Fielding, Ballance, Scriven, McDonald, and Johnson (2008) provide data on the percentage of "Haitians" in the population (see p. 45), as does the Bahamas national census. Since undocumented people often wish to remain invisible to data-gatherers and authorities, however, it is very difficult to know precisely how many exist within a population.
}

but no one knows the extent or type of statelessness that predominates. Statelessness is a condition that arises when a person is "not considered as a national by any State under the operation of its law" (United Nations Office of the High Commissioner for Human Rights [OHCHR], 1954, Article 1). This is the de jure, or international legal, definition of statelessness. A second type is de facto statelessness. De facto statelessness occurs when a person, who falls under the operation of a State's law, does not enjoy the rights or protections associated with that State's citizenship. The person's citizenship is consequently ineffective (Batchelor, 1998; Lynch, 2005; Manly, 2007). Millions of people globally suffer from de facto statelessness, and the United Nations High Commissioner for Refugees (UNHCR) ${ }^{4}$ recognizes that it is a problem (2009).

Regardless of the type of statelessness, stateless people around the world are vulnerable to exploitation, trafficking, discrimination and rights denial. Without citizenship from anywhere, State protection is almost non-existent. It is also difficult for a person to access State services, find legitimate employment, move freely in and out of the State of residence, and perform basic, everyday activities that citizens taken for granted. Some of the world's estimated 15 million stateless people (UNHCR, 2007) live in camps where they lack clean running water or adequate health and educational facilities. Others languish in detention centers because no country will recognize them as one of their own, and almost all suffer breaches of their basic human rights in some form or another. Arendt's children, as the most vulnerable of the stateless, are especially susceptible to violations of their rights and security. Youth Advocates Program International, for example, observes how sex traffickers target stateless children, "knowing that such children are vulnerable to manipulation and coercion” (Aird, Harnett, \& Shah, 2002, p. 3). Stateless children are also easy prey for forced labour and eviction, kidnapping, physical abuse and harassment (Lynch, 2008, p. 6; Aird et al., 2002, p. 7). Their rights to an identity, protection, health, education

\footnotetext{
${ }^{4}$ The second mandate of the UNHCR is the protection of stateless people; the first is the protection of refugees.
} 
and so on are often routinely violated.

During the summer of 2009, the author went to Nassau, The Bahamas, to investigate the question of statelessness. Sixteen semi-structured, elitelevel interviews were held on the subject ${ }^{5}$. Interviewees included former and current government officials, academics, community leaders, lawyers, a civil servant and a journalist. The majority of the interviewees were Bahamian and a few were Haitian. With the exception of one interviewee, all concurred that statelessness was a problem in the country. Based upon an examination of Haitian and Bahamian law (presented in this article), and supported by information garnered during the course of the interviews, de facto statelessness predominates in the country. ${ }^{6}$ It results despite the provision in Article 11 of the Haitian Constitution that "[a]ny person born of a Haitian father or Haitian mother who are themselves native-born Haitians and have never renounced their nationality possesses Haitian nationality at the time of birth" (Republic of Haiti, 1987). ${ }^{7}$

Thus, Bahamian-born children of Haitian migrants are Haitian citizens de jure (by law) if either of their parents was born in Haiti, and has not

\footnotetext{
${ }^{5}$ These interviews were anonymous and, according to the author's Institutional Review Board protocol, could not include vulnerable populations, such as Arendt's children. Future work needs to include interviews with Bahamianborn children of parents without status.

${ }^{6}$ According to Bahamian law, a person must renounce his or her original citizenship before acquiring Bahamian citizenship. It is therefore possible for de jure statelessness to arise in those instances when an individual is waiting to be inducted as a Bahamian citizen. Although the author attempted to find out the average duration a person could wait to be inducted as a Bahamian citizen after renouncing his or her original citizenship, responses from the relevant authorities varied to such a degree that no definitive answer can be provided.

${ }^{7}$ Additionally, Article II of the 1984 Haitian Nationality Law is clear that "[a]ny person born abroad, of a Haitian father and mother" possesses "Haitian nationality at birth" (Atwil, 1998). This is in contradistinction to the 1987 Constitution that declares that only one parent needs to be nativeborn Haitian.
}

renounced his or her Haitian citizenship, and can prove that he or she has said citizenship. ${ }^{8}$ Problems arise, and children consequently become de facto stateless, when the parent is of Haitian descent, but is not a "native-born" Haitian, or is undocumented or cannot prove possession of Haitian citizenship. International law recognizes the need to protect children from falling into this no-man's land of statelessness and asks that a State party to the 1961 Convention on the Reduction of Statelessness "grant its nationality to a person born in its territory who would otherwise be stateless" (U.N. OHCHR, 1961, Article 1). The Bahamas is not a party to this convention, however, and since it does not grant an automatic right to citizenship based upon birth on the territory (jus soli) to children born of non-citizen parents, the potential for statelessness is great.

While one government official felt that the precarious situation of this group of Arendt's children was not due to Bahamian laws and policies - it is "not necessarily stateless[ness] here [in The Bahamas], but it's a statelessness in their country [Haiti]. In other words... a child born in The Bahamas of Haitian parentage has the right to a Haitian passport. Nothing stops that" - this is an unfounded assumption. One cannot simply go into the Haitian Embassy in The Bahamas and acquire identifying documents because one "sounds" or "looks" Haitian. One must be able to prove that he or she is a native-born Haitian and this is often very difficult to do when a person does not possess the relevant identifying documents. Moreover, Bahamian citizenship and naturalization law, and The Bahamas' lack of accession to the 1961 statelessness convention, exacerbates the vulnerable position of these children.

While some may argue that the parents without status could return to Haiti and attempt to acquire proof of Haitian citizenship so that the Bahamian-

\footnotetext{
${ }^{8}$ Teff and Gonçalves Margerin point out that many children of Haitian ancestry born in the Dominican Republic do "not have automatic access to Haitian nationality" (2008, p. 2) because they were born to undocumented parents or parents seeking asylum. These and other groups of Haitians allegedly do not automatically receive Haitian citizenship.
} 
born child would formally acquire the parents' citizenship, the likelihood of the parents undertaking this course of action is slim. They may not want to risk such a journey for fear of being unable to re-enter The Bahamas. Furthermore, there is no guarantee that once a migrant parent has returned to Haiti he or she will be able to obtain the necessary documentation. As one interviewee remarked, "But if a child born in The Bahamas, or anywhere else, outside of Haiti, go[es] to Haiti right now they will have difficult[y] to get [a] document." Fletcher and Miller (2004) made a similar observation regarding Haitians in the Dominican Republic: "The Haitian government does not have a robust system in place to provide identity documents routinely to all its nationals, a problem that compounds the difficulties Haitian migrants face in securing legal entitlements once in the Dominican Republic” (p. 671-672).

Consequently, although the Haitian Constitution says (with the aforementioned caveats) that these children are Haitian citizens, in practice many are de facto stateless. While The Bahamas' position may be that these children's situation is the result of issues stemming from Haiti, this does not absolve it of its obligations, under international treaties it has ratified, to respect, protect and fulfil the human rights of all people, including Bahamian-born children of parents without status. Among the treaties ratified by The Bahamas, which apply directly to the question of the rights of Bahamian-born non-citizen children, are the CRC and the 1965 International Convention on the Elimination of All Forms of Racial Discrimination (ICERD). Table 1 contains a matrix of all the relevant treaties referred to in this article.

\section{BAHAMAS AS STATE PARTY}

The 1989 CRC seeks to provide children with explicit rights, protections, and recognition. It asks that States party to the convention give "due weight” to children's views, especially in administrative and legal proceedings (Article 12), and it stresses the right of the child to participate in matters that affect her. The CRC also requests that States make the child's "best interests...a primary consideration" (Article 3). According to many, this "best interests" principle undergirds the convention and, along with the right of nondiscrimination and participation, is considered fundamental for child survival and development (Archard \& Skivenes, 2009; UNHCR, 1994, p. 6). The CRC does not limit consideration of the child's "best interests," her right of participation in matters that affect her, and her right of nondiscrimination to her "legality" or citizenship status within a State.

When The Bahamas ratified the CRC in 1991 it made a reservation to Article 2 of the convention. Article 2 asserts that children have the rights enumerated in the convention irrespective of their or their parents', status, national or social origin or other factors beyond their control such as the colour of their skin or gender. Article 2 also asks States party to the convention to "take all appropriate measures to ensure that the child is protected against all forms of discrimination or punishment." Since the Bahamian Constitution denies automatic citizenship on jus soli grounds to children born of non-nationals, in 1991 The Bahamas made the following reservation to Article 2:

The Government of the Commonwealth of The Bahamas upon signing the Convention reserves the right not to apply the provisions of article 2 of the said Convention insofar as those provisions relate to the conferment of citizenship upon a child having regard to the Provisions of the Constitution of the Commonwealth of The Bahamas (United Nations, 2010, Ch. 4-11, p. 4).

While the right to a nationality (Article 7 of the CRC, Article 15 of the Universal Declaration of Human Rights, Article 24 of the International Covenant on Civil and Political Rights [ICCPR $]^{9}$ ) is not extended to Bahamian-born children of nonnational parents at birth, The Bahamas appears to agree that other CRC rights apply to children of parents without status since no further

\footnotetext{
${ }^{9}$ It is of note that the Bahamas, which became a State party to the ICCPR in 2008, made no similar reservation regarding Article 24, paragraph 3, of the ICCPR, which asserts the right of "[e]very child...to acquire a nationality." Presumably the government's earlier reservation regarding Article 2 of the CRC applies to this other international treaty, although it is not explicit.
} 
reservations were made. Beside the aforementioned principles of participation and best interests, the rights of the child in the CRC include: the right to life, survival and development (Article 6), the right to be cared for by her parents (Article 7) and not to be separated from them against her will (Article 9), and the right to an identity (Article 8), health (Article 24) and education (Article 28). As a human being, the child also has the rights enumerated in the Universal Declaration of Human Rights (UDHR, 1948), which include: the right to security of person (Article 3), recognition as a person before the law (Article 6), equality before the law and equal protection thereof (Article 7), judicial remedy (Article 8) and State protection of the family (Article 16), among others. Many of these rights are subject, in whole or in part, to violation when it comes to Bahamian-born children of undocumented Haitian parents in The Bahamas.

The child's right to security and to non-separation from her parents, for example, is placed in jeopardy when the government conducts immigration raids to remove undocumented persons from the country. According to newspaper accounts, these early-morning-hour immigration raids are conducted by defence force and immigration officers who allegedly act in an inhumane manner, force people from their homes, and whose actions lead to families being "torn apart” (Reynolds, 2009, p. A2; Lockhart, 2009, p. A3). One interviewee added that these raids result in Bahamian-born children being held at the detention facility, an institution that has not received positive reviews (Amnesty International, 2003). "[S]ometimes you find more children who born in The Bahamas than Haitians themselves" in the detention centre. This interviewee also stated that Bahamian-born and educated students sometimes spend weeks or months in detention because of their parents' undocumented status, while others are deported. These raids and the consequent detention and/or deportation of the child are inimical to creating a climate conducive to securing the best interests of the child or her right to development.

The right to judicial remedy in such instances is unlikely to be extended. The Committee on the Elimination of Racial Discrimination (CERD), which oversees implementation of ICERD, expressed concern that The Bahamas automatically detains undocumented migrants "without such detention being subjected to judicial review" (U.N. CERD, 2004b, p. 5). While the committee advised The Bahamas to ensure "that non-citizens have equal access to effective remedies, including the right to challenge expulsion orders, and are allowed effectively to pursue such remedies" on a nondiscriminatory basis (U.N. CERD, 2004a), The Bahamas made it clear in its 2009 Universal Periodic Review report that it would not heed the recommendation that it "subject any detention of migrants, refugees or asylum seekers to judicial review and ensure that persons are informed of their rights” (U.N. Human Rights Council, 2009, p. 19).

This lack of judicial review and remedy sets a precedent wherein Bahamian-born children of non-citizen parents are put at risk of deportation, or separation from their parents, and it consequently weakens their right of participation in matters that affect them. As one interviewee noted, "many children born here [in The Bahamas] have been repatriated with their mother, with their parents, particularly the mother, at [an] early age." The undocumented parents, "before leaving, they don't even think about having an official document here. They cannot, they cannot have a passport, but at least they could have a travel document. They did not. Then no vaccination, nothing; how you going to prove ... [birth in The Bahamas]?”

While the undocumented parents in this interviewee's example were unable to secure a Bahamian birth certificate for their Bahamianborn child, The Bahamas largely appears to provide birth certificates to Bahamian-born children - an important part of the child's right to an identity. According to Johnson et al.'s investigation for the International Organization for Migration, most of the children born to their Haitian migrant participants acquired a Bahamian birth certificate (2005, p. 71). Additionally, The Bahamas provides one of the key "obligatory rights" of non-citizen children (Bhabha, 2009a, p. 439) - free primary education regardless of legal status - and goes even further to provide free secondary education in public schools. One interviewee contended, however, that some 
children still have difficulty attending school as "people with prejudice" prevent Haitians from registering their children: "You go to a place to register your children, 'Oh, no, no. It is not the time yet. Come in three weeks.' When you come in three weeks that's [the registration is] finished."

This participant's assertion of discrimination in education finds support in the CERD's concluding observations on The Bahamas wherein it expressed concern "at reports of statements and press articles inciting racial discrimination against migrants, Haitians in particular, and actual discrimination against migrants in fields such as education” (2004b, p. 3). In addition, Johnson et al., commenting on a series of newspaper articles about the education of Bahamian-born children of Haitian parents, noted that "it came to light that only students with documentation (birth certificate, residency papers, passport, etc.) were permitted to register for school” (2005, p. 8). One interviewee added that as a result of the discriminatory treatment in schools, some Haitians have set about creating their own school. It thus appears that the right to an education is not always provided in a discrimination-free environment even though "[e]ducation facilities [have] been extended to the children of undocumented Haitian immigrants" (U.N. CERD, 2004c, p. 3).

Although another interviewee noted that children of undocumented Haitians are unable to have their parent(s) accompany them for medical treatment overseas, The Bahamas fulfils the second obligatory right of non-citizen children: the "recognition of everyone's right to the enjoyment of the highest attainable standard of physical and mental health” (Bhabha, 2009a, p. 439). The interviewee who earlier noted that children of Haitians are sometimes denied registration in school stated that "[h]ealth care they provide for everyone.” Another interviewee similarly observed that The Bahamas' policy is to "make sure you are healthy" and that a person has access to "the health system irrespective of [his or her] illegal status." While more data is needed, these statements appear to support The Bahamas' official report to the Committee on the Rights of the Child that "[c]hildren of undocumented migrants also enjoy the benefits of free health care" (U.N. Committee on the Rights of the Child,
2004, p. 50).

Despite this important achievement, the Committee on the Rights of the Child is still "concerned that societal discrimination persists against vulnerable groups of children; including...Haitian immigrant children" (U.N. Committee on the Rights of the Child, 2005b, p. 5). Bahamian government reports, acts and policies generally ignore the special needs and concerns of Bahamian-born children of noncitizen parents. For instance, while The Bahamas passed The Status of Children Act, "abolish[ing] the distinction between legitimate or children born in wedlock and illegitimate or children born out of wedlock" (Bahamas Ministry of Social Services and Community Development, 2003, p. 40), it did not consider a similar provision abolishing discrimination against non-citizen children. The 2007 Child Care Protection Act is also remarkably silent on the rights of migrant or non-citizen children and does not contain an antidiscrimination clause either.

Furthermore, in its belated report to the Committee on the Rights of the Child in 2003, The Bahamas did not account for the special situation of children born to parents without status in the country. When asked by the committee what areas The Bahamas considers to be of special concern with regard to implementing the CRC, the Bahamian delegation emphasized family dissolution and child abuse (Bahamas Ministry of Social Services and Community Development, 2003, p. 49-50). In its follow-up report to the committee's questions, the delegation stressed child cruelty, neglect and protection, but no specific consideration was given to the predicament of children born to non-citizens, especially undocumented migrants. This absence is striking when the committee considers immigrant children to be one of the three "most vulnerable groups" in addition to children with disabilities and those living in poverty (U.N. Committee on the Rights of the Child, 2005b, p. 4).

The predominant focus on the needs and protections of Bahamian "citizen" children, as opposed to Bahamian-born or resident children generally, is also reflected in one of the Minister of State for Social Services' monthly child 
protection messages. In this message she recognizes "the right of every Bahamian child to a living environment that nurtures his or her physical, mental, spiritual, moral and social development” (Butler-Turner, 2008, para. 2). She adds that "[o]ur children are our future and perhaps the nation's most valuable resource. How we care for them will determine the extent of their success in the future" (para. 9). While the Minister's message is laudable, it is unfortunate that it does not consider Arendt's children and how they form part of the Bahamian social, if not legal, fabric, and how they have the potential to be as valuable a resource to the country as their Bahamian-citizen counterparts. As an interviewee cautioned,

One thing people don't understand here in The Bahamas, most of the foreigners - most of the Haitian[s] living here, they are here to stay...Sooner or later that might be a problem for the country...I understand those who are illegal, they cannot stay; you want to repatriate them. But those who are born here, their parent[s] come here - treat them fairly because they're going to be part of the population.

This echoes Bhabha's concern about the inclusion of Arendt's children in the communities where they were born and reside. She asks, "What sort of juror or voter with a contribution to make to his or her peers is one who has been forced to live outside the community during the premajority period?” (2009b, p. 219). The Bahamas might similarly ask what sort of "citizens-in-themaking" are they shaping with their current policies and laws? Upon reaching 18, Bahamianborn children of non-citizens only have the right to apply for citizenship within a one-year timeframe, and even then they may be denied citizenship or have to wait, as many interviewees pointed out, for years to acquire Bahamian citizenship. One interviewee observed that The Bahamas was "creating more Haitians, or more foreigners, than Bahamians" with its current immigration and citizenship policies, and that it was ludicrous to expect these children, who "for the first 18 or 25 years of their lives they were not treated as citizens," to suddenly accept The Bahamas as "their country" and to show "loyalty" even if eventually provided Bahamian citizenship.
The exclusion of Arendt's children from the Bahamian polity for the most important, formative years of their life may have portentous consequences for the country.

\section{MEANS OF INTEGRATING ARENDT'S CHILDREN}

"The responsibility to implement the best interests principle [of the CRC] is first and foremost that of a State, stemming from its international legal obligations" (UNHCR, 2008, p. 26), and it is widely accepted in the human rights literature that the State has the responsibility to respect, protect and fulfil human rights (UN General Assembly, 2005, p. 3; Green, 2001, p. 1071; Maastricht Guidelines, 2000). As such, the Bahamian State as agent must be the focus of change to address the needs of this group of Arendt's children. Consequently, in line with its obligation to respect, the Bahamian government must not deprive any child, irrespective of nationality, of those rights outlined in the Universal Declaration of Human Rights or in conventions to which it is a State party. ${ }^{10}$ This includes providing education and health-care in a discrimination-free environment and refraining from placing children in situations where they are insecure in their person or separated from family members.

Under its obligation to protect, The Bahamas must not permit other agents-whether private individuals, companies or other third parties-to deprive the child of any of these enumerated rights. Thus, when people allegedly treat Haitians in a discriminatory manner, and when the media portrays Haitians in a negative way (Johnson et al., 2005), the Bahamian government has the responsibility to advocate against this type of discrimination. According to its responsibility to fulfil human rights, the Bahamian government should use its resources to the best of its ability to provide an environment conducive to the realization of the rights of all children, regardless of national origin or other status.

While The Bahamas does not have a formal policy of purposively depriving Bahamian-born children of parents without status of their rights, it often

\footnotetext{
${ }^{10}$ These treaties include ICERD, ICCPR, International Covenant on Economic, Social and Cultural Rights (ICESCR) and CRC.
} 
ends up doing so in practice. This may result from the country's acknowledgement that noncitizens may be treated differently from Bahamian citizens when it comes to human rights. In its reservation to ICESCR, for example, the government states:

The Government of The Bahamas interprets non-discrimination as to national origin as not necessarily implying an obligation on States automatically to guarantee to foreigners the same rights as to their nationals. The term should be understood to refer to the elimination of any arbitrary behavior but not of differences in treatment based on objective and reasonable considerations, in conformity with principles prevailing in democratic societies (United Nations, 2010, Ch. 4-3, p. 3).

The Bahamas' position is not unusual. International law recognizes that citizens and noncitizens may be treated differently when it comes to political rights and freedom of movement, and that developing countries may differentiate between the two categories of people, in a "narrow" fashion, when it comes to providing economic rights (U.N. Commission on Human Rights, 2003, p. 10). All other rights, however, are supposed to be applied equally to all regardless of national or ethnic origin, or other status. Being a non-citizen, therefore, should not jeopardize the enjoyment of basic human rights. Precisely which human rights The Bahamas considers less important for non-citizens to have on par with citizens is not defined in The Bahamas' ICESCR reservation. However, an examination of Chapter 3 of the Bahamian Constitution (Bahamas Government, 1973a) reveals that every person has the right to: (a) life, liberty, security of the person and the protection of the law; (b) freedom of conscience, of expression and of assembly and association; and (c) protection for the privacy of his home and other property.

Other rights and protections include protection from slavery, forced labour, and arbitrary arrest and detention. The Constitution declares that these rights are supposed to apply equally to all "whatever his race, place of origin, political opinions, colour, creed or sex" (para. 15). Yet
Article 26.9 of the Constitution allows that laws may be discriminatory in content or effect when it comes to Articles 21 through 25 of the Constitution. These articles deal with nonconsensual search of person and property; freedom of thought, conscience and religion; freedom of expression; freedom of peaceful assembly and association; and freedom of movement, respectively. Laws may consequently discriminate or afford "different treatment to different person[s] attributable wholly or mainly to their respective descriptions by race, place of origin, political opinions[,] colour or creed" (Article 26.3) when it is "reasonably required" for matters of public safety, order, health and morality, and for the defense of the country (Articles 21.2.a, 22.5, 23.2, 24.2 and 25.2.a).

Since these provisions provide numerous potential grounds for restricting the human rights of noncitizens in the areas of speech, assembly, privacy and others, The Bahamas, a State party to ICERD since 1975, ought to consider laying out its official position on discrimination. It is not enough to declare that "the Constitution of the Commonwealth of The Bahamas entrenches and guarantees to every person in the Commonwealth of The Bahamas the fundamental rights and freedoms of the individual irrespective of his race or place of origin" (United Nations, 2010, Ch. 42, p. 4) when the aforementioned Constitutional caveats exist. The Bahamas thus needs to clarify its position regarding human rights, non-citizens and the Constitution. Additionally, in line with its international obligations and its own vested interest in domestic stability (Sears, 1994, p. 15), The Bahamas needs to evaluate how best it can integrate the Bahamian-born children of parents without status who face many problems in the country of their birth:

... we have a number of persons who are born here and they are born to illegal persons, so they're not Bahamian, they're not - they have nothing. They have no documentation and as a result of that, as they get older, and they try to make their way in life, they cannot open up a bank account, there's difficulty travelling, trying to get into schools, and it poses a problem. (Anonymous interviewee, 2009)

With the exception of government officials, most 
interviewees felt that one means of integration would be for The Bahamas to amend its Constitution so that Bahamian-born children acquire Bahamian citizenship at birth regardless of parents' nationality. One participant opined that

there's nothing to be gained, in my opinion, from telling a person you must wait until 18 to get the citizenship... What you do in fact do is frustrate and alienate that person for 18 years. How does that serve the public good?

Another said that The Bahamas was "creating more liabilities than assets" or "more Haitians than Bahamians" with its current citizenship laws and policies of exclusion. These interviewees' assertions coincide with Johnson et al.'s observation that many Bahamian commentators and opinion article writers are critical of present citizenship laws and desirous of jus soli citizenship acquisition for Bahamian-born children of non-citizen parents (2005, p. 15).

It is improbable that the Constitution will be amended to reflect the interviewees' and commentators' suggestion, however, as the commentators from Johnson et al.'s report and the interviewees for the present study are not necessarily representative of public opinion. While an analysis of Bahamian public opinion on the matter has yet to be performed, ${ }^{11}$ in 2002 the Bahamian public rejected a constitutional amendment (Bahamas Constitution [Amendment] Act, 2002) that was going to allow Bahamian women, married to foreigners, to pass on citizenship to their children born outside of The Bahamas (International Foundation for Electoral Systems, 2006). Consequently, Bahamian women married to foreigners, who bear children overseas, are still unable to pass on citizenship to their children automatically like their male national counterparts. $^{12}$ If Bahamian women are unable to

\footnotetext{
${ }^{11}$ Belton (in press) evaluates some of the reasons why Haitian and Bahamian civil society have yet to mobilize around the rights of undocumented Haitians. It is not, however, an analysis of survey data on the subject of citizenship and statelessness.

${ }_{12}$ Thus the reservation that the Bahamas made to Article 9, paragraph 2 of the Convention on the Elimination of All Forms of Discrimination Against
}

secure citizenship in all instances for their children, the likelihood that the Constitution will be amended to secure citizenship at birth for Bahamian-born children of non-citizens is remote.

Another unlikely possibility to help secure the best interests and rights of Bahamian-born children of parents without status is for The Bahamas to become a State party to the 1954 Convention relating to the Status of Stateless Persons and the 1961 Convention on the Reduction of Statelessness. Although a few island nations, such as Antigua and Barbuda, Barbados, the Dominican Republic, St. Vincent and the Grenadines, and Trinidad \& Tobago have signed either the 1954 or 1961 statelessness conventions, The Bahamas, as one interviewee remarked, has "[n]o...movement towards signing them." Consequently, The Bahamas has not made a commitment to reduce statelessness globally or to ensure that stateless people enjoy at least those basic rights provided for in the 1954 convention. Similarly, the prospect of The Bahamas becoming a State party to the 1990 International Convention on the Protection of the Rights of All Migrant Workers and Members of Their Families (CMW) is slim, given that tens of thousands of such workers and their children are estimated to reside in the country.

Another option is the creation of a special status for Bahamian-born children of migrants who reside in The Bahamas. While no human right to belong (in the form of residence or right of place) exists, political theorists such as Walzer and Barbieri argue that the right of place is one of the most basic rights that should be extended to people in order to avoid tyranny (Walzer, 2008, p. 157; Barbieri, 1998, p. 157). Additionally,

Women (CEDAW) still stands. This Article asserts that "States parties shall grant women equal rights with men with respect to the nationality of their children." Of the 186 States party to CEDAW, The Bahamas, along with Bahrain, Brunei Darussalam, North and South Korea, Iraq, Jordan, Kuwait, Lebanon, Morocco, Oman, Qatar, Saudi Arabia, Syria, Tunisia and the United Arab Emirates, refuse to be bound by Article 9, paragraph 2 of the convention and allow for discrimination against women when it comes to passing on citizenship (United Nations, 2010, Ch. 4-8, p. 4). 


\section{Bhabha explains how}

... the place of residence has a pervasive influence even for very young children; it affects children's life expectancy, their physical and psychological development, material prospects, and general standard of living. The fact of belonging to a country fundamentally affects a child's family and private life, during childhood and beyond. Yet children, particularly young children, are often considered parcels that move easily across borders with their parents and without particular cost (2009a, p. 448).

Bhabha's observation demonstrates what little voice Arendt's children have in decisions that affect them, as evidenced in the Bahamian case by the use of raids and deportation orders that do not make the child's best interests a "primary concern."13 The prevailing sentiment is, as noted in the interviewee's comment in the epigraph, that an undocumented person "should not be able to produce a person who becomes legal when they are born here." The Bahamas is not the only State in the region, or the world for that matter, to ignore the best interests of the non-citizen child of undocumented parents. As Thomas-Hope remarks,

[t]he problem of stateless children has arisen in Anguilla and in the Turks and Caicos Islands in recent years. In July 2002, the issue became a scandal when the children of Haitian parents but born in the Turks and Caicos Islands were threatened with expulsion (termed 'repatriation') to Haiti. According to unofficial sources, some children had actually been sent back, but were returned by the authorities on grounds that they were not Haitian citizens. The children demonstrated with placards, using the publicity given to a protected species of reptile, the iguanas, which had been dubbed as 'belongers', in order to encourage their protection. The children of Haitian parents born in the same islands were now considered 'non-belongers' and

\footnotetext{
${ }^{13}$ Bhabha (2003 and 2009a), Lidén and Rusten (2007) and Sawyer (2006) discuss how State immigration and naturalization policies seldom consider the needs and concerns of non-citizen children in matters that affect them.
}

subsequently were in danger [of] being expulsed (2003, p. 11-12).

The vulnerability of these children is clear and The Bahamas and other States in the region need to begin the process of making these children's well-being, security and best interests a primary concern. This does not mean that the voice and interests of the child of parents without status outweighs other concerns or the voice of citizen children. It simply means that they should no longer be ignored in policy decisions that affect them. Moreover, the benefit of passing a law that creates a special status for this group of noncitizen children is that it may be more integrative than current policies. The non-citizen child would grow up knowing that she is no less worthy of protection and respect than the citizen child and that her status within her country of birth and residency is secure. This special status could prove invaluable for Bahamian-born children of undocumented Haitian parents who lack effective citizenship from Haiti and who are not permanent residents of The Bahamas.

Assuming political will and public support are lacking to create such a status, however, The Bahamas could continue to use its current citizenship laws but allow a "fast-track" procedure for Bahamian-born children of non-citizen parents. This process would be transparent in that application procedures would be widely disseminated in kreyol among Haitian populations. It would be a special "track" in that Bahamian-born children of non-citizen parents who reside in The Bahamas would have their applications pushed to the front of the queue in citizenship considerations when they apply at 18 . It would be "fast" in that Cabinet decisions would be made within a one-year interval from the date of application so that high-school graduates do not have to put their lives on hold too long as they await Cabinet's response. This fast-track procedure should also be subject to judicial review since, as one interviewee commented, "there is just so much room for abuse" and "[i]t's a seriously flawed approach" when decisions pertaining to citizenship depend on elected officials within the executive branch of 
government. ${ }^{14}$

If such a fast-track procedure is too controversial to implement, The Bahamas needs to consider policy, as opposed to legal, alternatives for integrating Arendt's children. For instance, if it has not already done so, The Bahamas might consider appointing at least one non-national representative to the National Child Protection Council and the National Committee for Families and their Children. In this manner, the Bahamianborn non-citizen child's concerns and needs could be voiced within a national forum. It would also be advantageous for all children in The Bahamas if either the Council or Committee could be provided the means and the mandate "to receive and handle complaints related to the Convention on the Rights of the Child," which neither one is currently set up to do (Bahamas Ministry of Social Services and Community Development, 2003, p. 45). Moreover, the Council should consider implementing an anti-discrimination campaign in addition to "Operation Protect Our Children" (p. 43) since the particular vulnerabilities that Bahamian-born children of parents without status face are often linked to discrimination against them.

While these suggestions are in no way comprehensive, they are a means by which to foment discussion around the rights and best interests of Arendt's children in The Bahamas. As Bhabha notes, "rights believers...have an obligation to raise and stimulate discussion of the difficult and contentious issues that arise in actualizing migrant children's right to have rights" (2009a, p. 451). This article attempts to initiate such a discussion by examining the current legal and political context surrounding the rights and best interests of Bahamian-born non-citizen children in The Bahamas. Although The Bahamas generally fulfils its international law obligations

${ }^{14}$ The Bahamas Nationality Act of 1973 would have to be amended first, however, since it states that the minister responsible for granting or denying citizenship applications "shall not be required to assign any reason for the grant or refusal of any application or the making of any order under this Act the decision upon which is at his discretion; and the decision of the Minister on any such application or order shall not be subject to appeal or review in any court". when it comes to the child's rights to an identity, healthcare and education, this article shows that it does not always adequately take into account Arendt's children's "best interests" in matters that affect them or provide rights to them in a discrimination-free environment. In sum, The Bahamas needs to consider carefully its role in the perpetuation of statelessness and the consequences of not providing these children with the means to be successful in a future that they may one day share with Bahamians as citizens. 


\section{Table 1}

Status of Bahamas' Ratification of International Treaties Applicable to Arendt's Children

Treaty

Convention relating to the

Status of Stateless Persons

(1954)

Convention on the Reduction Not ratified

of Statelessness (1961)

International Convention on

the Elimination of All Forms of

Racial Discrimination (1965)

ICERD
Ratification Date

Not ratified

Applicable Reservation (R) or Declaration (D)

5 August 1975

"the Constitution of the Commonwealth of The Bahamas entrenches and guarantees to every person in the Commonwealth of The Bahamas the fundamental rights and freedoms of the individual irrespective of his race or place of origin" (D)

International Covenant on Civil 23 December 2008

and Political Rights (1966)

ICCPR

International Covenant on

Economic, Social and Cultural

Rights (1966)

ICESCR
23 December 2008 "The Government of The Bahamas interprets non-discrimination as to national origin as not necessarily implying an obligation on States automatically to guarantee to foreigners the same rights as to their nationals. The term should be understood to refer to the elimination of any arbitrary behavior but not of differences in treatment based on objective and reasonable considerations, in conformity with principles prevailing in democratic societies" (D)

"The Government of the Commonwealth of The Bahamas does not consider itself bound by the provisions of article $2(\mathrm{a}), \ldots$ article 9 , paragraph 2 , ... article $16(\mathrm{~h}), \ldots$ [and] article 29 , paragraph 1 , of the Convention" (R)

"The Government of the Commonwealth of The Bahamas upon signing the Convention reserves the right not to apply the provisions of article 2 of the said Convention insofar as those provisions relate to the conferment of citizenship upon a child having regard to the Provisions of the Constitution of the Commonwealth of The Bahamas" (R)

International Convention on Not ratified

the Protection of the Rights of

All Migrants Workers and

Members of their Families

(1990)

CMW

Source: United Nations. (2010). Multilateral treaties deposited with the Secretary-General [Database].

New York, NY: Author. 


\section{REFERENCES}

Aird, S., Harnett, H., \& Shah, P. (2002). Stateless children: Youth who are without citizenship. Washington, DC: Youth Advocate Program International. Retrieved from http://www.yapi.org/old/publications/bookletseri es/Stateless.pdf

Amnesty International. (2003). Bahamas: Forgotten detainees? Human rights in detention in The Bahamas. (AI Index 14/005/2003). Retrieved from http://www.amnesty.org/en/library/info/AMR14/ 005/2003.

Archard, D., \& Skivenes, M. (2009). Balancing a child's best interests and a child's views. International Journal of Children's Rights, 17, 1-21. doi: 10.1163/157181808X358276.

Arendt, H. (1948/2004). The origins of totalitarianism. New York, NY: Schocken Books.

Atwil, N. (1998). Report of the Law Library of Congress on Haitian national legislation (LOC Rept No. 99-1104). Washington, DC: Library of Congress. Retrieved from http://www.uscis.gov/ilink/docView/AFM/HTM L/AFM/0-0-0-1/0-0-0-26573/0-0-0-31594.html

Bahamas Constitution (Amendment) Act. (2002). Retrieved from http://www.lexbahamas.com/Microsoft\%20Wor d\%20\%20The\%20Bahamas\%20Constitution\%20_Am endment_\%20Act\%202002.pdf

Bahamas Government. (1973a). The constitution of the Commonwealth of The Bahamas.

Retrieved from http://laws.bahamas.gov.bs/statutes/statute_THE _CONSTITUTION.html

Bahamas Ministry of Social Services and Community Development. (2003).

Implementation of the Convention on the Rights of the Child: Responses to issues to be taken up in consideration of the initial report of the Bamamas [sic] CRC/C/8/Add50. Retrieved from http://www2.ohchr.org/english/bodies/crc/docs/ AdvanceVersions/CRC.C.RESP.BHS.doc

Bahamas Nationality Act [CH 190] (1973) Bahamas. Retrieved from
http://laws.bahamas.gov.bs/statutes/statute_CHA PTER_190.html\#Ch190s9

Barbieri, W. A., Jr. (1998). Ethics of citizenship: Immigration and group rights in Germany. Durham, NC: Duke University Press.

Batchelor, C. C. (1998). Statelessness and the problem of resolving nationality status.

International Journal of Refugee Law, 10(1), 5683. doi: 10.1093/ijrl/10.1-2.156.

Belton, K. A. (in press). Dry land drowning or rip current survival? Haitians without status in The Bahamas. Ethnic and Racial Studies.

Benhabib, S. (2004). The rights of others: Aliens, residents and citizens. Oxford, England: Oxford University Press.

Bhabha, J. (2003). The citizenship deficit: On being a citizen child. Society for International Development, 46(3), 53-59. doi: 10.1177/10116370030463008.

Bhabha, J. (2009a). Arendt's children: Do today's migrant children have a right to have rights? Human Rights Quarterly, 31, 410-451. doi: 10.1353/hrq.0.0072.

Bhabha, J. (2009b). The 'mere fortuity of birth'? Children, mothers, borders, and the meaning of citizenship. In S. Benhabib \& J. Resnik (Eds.), Migrations and mobilities: Citizenship, borders and gender (pp. 187-227). New York: New York University Press.

Butler-Turner, L. (2008). Child protection month message. Retrieved from

http://www.bahamas.gov.bs/bahamasweb2/home .nsf/vContentW/Child+Abuse+Prevention--

Welcome--

Minister+of+State+Message! Opendocument

Child Care Protection Act No. 1 of 2007. (2007)

Bahamas. Retrieved from http://laws.bahamas.gov.bs/pdf/THECHILDCA REPROTECTIONACT20041.pdf

Fielding, W. J., Ballance, V., Scriven, C., McDonald, T., \& Johnson, P. (2008). The stigma of being "Haitian" in The Bahamas. The College of The Bahamas Research Journal, 14, 38-50.

Fletcher, L., \& Miller, T. (2004). New perspectives on old patterns: forced migration of 
Haitians in the Dominican Republic. Journal of Ethnic \& Migration Studies, 30(4), 659-679. doi: 10.1080/13691830410001699504.

Green, M. (2001). What we talk about when we talk about indicators: current approaches to human rights measurement. Human Rights Quarterly, 23(4), 1062-1097. doi: 10.1353/hrq.2001.0054.

International Foundation for Electoral Systems. (2006). Election profile for Bahamas: Results. Retrieved from http://www.electionguide.org/results.php?ID=40 8

International Organization for Migration. (2010). Facts and figures. Retrieved from http://www.iom.int/jahia/Jahia/aboutmigration/facts-and-figures/lang/en\#1

Johnson, P., Ballance, V., Fielding, W., MacDonald, T., Scriven, C., \& Stuart, D. (2005). Haitian migrants in The Bahamas: a report for the International Organisation for Migration. Retrieved from http://www.iom.int/jahia/webdav/site/myjahiasit e/shared/shared/mainsite/published_docs/books/ Haitian_Migrants_Report.pdf

Lidén, H., \& Rusten, H. (2007). Asylum, participation and the best interests of the child: new lessons from Norway. Children \& Society, 21, 273-283. doi: 10.1111/j.10990860.2007.00099.x.

Lockhart, J. (2009, July 31). Haitian community slams authorities after Abaco raid. The Tribune. p. A3.

Lynch, M. (2005). Lives on hold: The human cost of statelessness. Washington, DC: Refugees International. Retrieved from http://www.refintl.org/policy/in-depthreport/lives-hold-human-cost-statelessness

Lynch, M. (2008). Futures denied: Statelessness among infants, children and youth. Washington, DC: Refugees International. Retrieved from http://www.refugeesinternational.org/sites/defau lt/files/Stateless_Children_FINAL.pdf

Maastricht guidelines on violations of economic, social and cultural rights. (2000). In United Nations Committee on Economic, Social and Cultural Rights. Substantive issues arising in the implementation of the international covenant on economic, social and cultural rights (pp 16-24). (E/C.12/2000/13). Retrieved from http://www1.umn.edu/humanrts/instree/Maastric htguidelines_.html/

Manly, M. (2007) The spirit of Geneva: Traditional and new actors in the field of statelessness. Refugee Survey Quarterly, 26(4), 255-261. doi: 10.1093/rsq/hdi0288

Ong, A. (2006). Mutations in citizenship. Theory, Culture \& Society, 23(2/3), 499-505. doi: $10.1177 / 0263276406064831$.

Republic of Haiti. (1987). Haitian constitution. Retrieved from http://pdba.georgetown.edu/constitutions/haiti/h aiti1987.html

Reynolds, M. (2009, August 5). Claims of inhumane treatment during immigration raid. The Tribune. p. A2.

Sassen, S. (2003). The repositioning of citizenship: Emergent subjects and spaces for politics. CR: The New Centennial Review, 3(2), 41-66. doi: 10.1353/ncr.2003.0028.

Sawyer, C. (2006). Not every child matters: the UK's expulsion of British citizens. The International Journal of Children's Rights, 14(2), 157-185. doi: $10.1163 / 157181806777922720$.

Sears, A. (1994). The Haitian question in The Bahamas. Journal of The Bahamas Historical Society, 16(1), 10-20.

Smith, L. (2008). Migration report: Time for a rational, non-partisan Haitian policy. Bahama Pundit [Web log post]. Retrieved from http://www.bahamapundit.com/2008/08/mikgrat ion-repo.html

Southwick, K., \& Lynch, M. (2009). Nationality rights for all: A progress report and global survey on statelessness. Washington, DC: Refugees International. Retrieved from http://www.refugeesinternational.org/sites/defau lt/files/RI\%20Stateless\%20Report_FINAL_031 109.pdf

Soysal, Y. N. (1998). Toward a postnational model of membership. In G. Shafir (Ed.), The citizenship debates (pp. 189-217). Minneapolis: University of Minnesota Press. 
Status of Children Act [CH 130] (2002).

Bahamas. Retrieved from

http://laws.bahamas.gov.bs/statutes/statute_chap ter_130.html

Teff, M., \& Gonçalves Margerin, M. (2008). Dominican Republic: Time to move forward to reduce statelessness. Washington, DC: Refugees International. Retrieved from http://www.refintl.org/sites/default/files/DRstate less_052808.pdf

Thomas-Hope, E. (2003). Irregular migration and asylum seekers in the Caribbean. Retrieved from http://www.wider.unu.edu/publications/working -papers/discussion-papers/2003/en_GB/dp2003048/

United Nations. (1948). Universal declaration of human rights. Retrieved from http://daccess-ddsny.un.org/doc/RESOLUTION/GEN/NR0/043/8 8/IMG/NR004388.pdf?OpenElement

United Nations. (1954). Convention relating to the status of stateless persons. Retrieved from http://treaties.un.org/doc/Publication/MTDSG/V olume\%20I/Chapter\%20V/V-3.en.pdf

United Nations. (1961). Convention on the reduction of statelessness. Retrieved from http://treaties.un.org/doc/Publication/UNTS/Vol ume\%20989/volume-989-I-14458-English.pdf

United Nations. (1965). International convention on the elimination of all forms of racial discrimination. Retrieved from http://treaties.un.org/doc/Publication/MTDSG/V olume\%20I/Chapter\%20IV/IV-2.en.pdf

United Nations. (1966a). International covenant on civil and political rights. Retrieved from http://treaties.un.org/pages/ViewDetails.aspx?src $=$ TREATY\&mtdsg_no=IV$4 \&$ chapter $=4 \&$ lang $=$ en

United Nations. (1966b). International covenant on economic, social and cultural rights.

Retrieved from http://treaties.un.org/doc/Publication/MTDSG/V olume\%20I/Chapter\%20IV/IV-3.en.pdf

United Nations. (1979). Convention on the elimination of all forms of discrimination against women. Retrieved from http://treaties.un.org/doc/Publication/MTDSG/V olume\%20I/Chapter\%20IV/IV-8.en.pdf
United Nations. (1989). Convention on the rights of the child. Retrieved from

http://treaties.un.org/doc/Publication/MTDSG/V olume\%20I/Chapter\%20IV/IV-11.en.pdf

United Nations. (1990). International convention on the protection of the rights of all migrant workers and members of their families.

Retrieved from

http://reaties.un.org/doc/Publication/MTDSG/V olume\%20I/Chapter\%20IV/IV-13.en.pdf

United Nations. (2010). Multilateral treaties deposited with the Secretary-General.

[Database]. Retrieved from

http://treaties.un.org/Home.aspx?lang=en

United Nations Commission on Human Rights. (2003). Prevention of discrimination: The rights of non-citizens: Addendum: Examples of practices with regard to non-citizens (E/CN.4/Sub.2/2003/23). Retrieved from http://www.unhchr.ch/huridocda/huridoca.nsf/e0 6a5300f90fa0238025668700518ca4/d8c2dada6b f34ca6c1256d79004bfa94/\$FILE/G0314395.pdf

United Nations Committee on the Elimination of Racial Discrimination. (2004a). General recommendation no. 30: Discrimination against non-citizens. Retrieved from http://www.unhchr.ch/tbs/doc.nsf/(Symbol)/e39 80a673769e229c1256f8d0057cd3d?Opendocum ent

United Nations Committee on the Elimination of Racial Discrimination. (2004b). Consideration of reports submitted by states parties under Article 9 of the convention: Concluding observations of the Committee on the Elimination of Racial Discrimination: Bahamas (CERD/C/64/CO/1). Retrieved from http://www.universalhumanrightsindex.org/docu ments/824/259/document/en/pdf/text.pdf

United Nations Committee on the Elimination of Racial Discrimination. (2004c). Fifth to fourteenth periodic reports of The Bahamas (CERD/C/SR.1620). Retrieved from http://www.unhchr.ch/tbs/doc.nsf/898586b1dc7 b4043c1256a450044f331/7756f4e5ec0f6f5fc12 56e67005c1545/\$FILE/G0440576.pdf

United Nations Committee on the Rights of the Child. (2005a). Consideration of reports of states parties: Initial report of The Bahamas 
(CRC/C/SR.1014). Retrieved from http://www.unhchr.ch/tbs/doc.nsf/(Symbol)/CR C.C.SR.1014.En?OpenDocument

United Nations Committee on the Rights of the Child. (2005b). Concluding observations: The Bahamas (CRC/C/15/Add.253). Retrieved from http://www.unhchr.ch/tbs/doc.nsf/898586b1dc7 b4043c1256a450044f331/023cb40668ee03c0c1 257018004fac02/\$FILE/G0540851.pdf

United Nations Committee on the Rights of the Child. (2004). Consideration of reports submitted by States parties under Article 44 of the convention: Initial reports of states parties due in 1993: Bahamas (CRC/C/8/Add.50).

Retrieved from http://www.unhchr.ch/tbs/doc.nsf/898586b1dc7 b4043c1256a450044f331/099b149b0597db84c1 256ee80033b9b6/\$FILE/G0440188.pdf

United Nations General Assembly. (2005). In larger freedom: Towards development, security and human rights for all (A/59/2005). Retrieved from http://www.un.org/largerfreedom/contents.htm http://daccess-ddsny.un.org/doc/UNDOC/GEN/N05/270/78/PDF/ N0527078.pdf?OpenElement

United Nations High Commissioner for Refugees. (1994). Refugee children: Guidelines on protection and care. Retrieved from http://www.unhcr.org/refworld/docid/3ae6b3470 .html

United Nations High Commissioner for Refugees. (2007). Q \& A: The world's 15 million stateless people need help. Retrieved from http://www.unhcr.org/464dca3c4.html

United Nations High Commissioner for Refugees. (2008). UNHCR guidelines on determining the best interests of the child. Retrieved from http://www.unhcr.org/cgibin/texis/vtx/search?page=search\&docid $=4566 \mathrm{~b}$ 16b2\&query=UNHCR Guidelines on Determining the Best Interests of the Child

United Nations High Commissioner for Refugees. (2009). What is statelessness? Retrieved from http://www.unhcr.org/pages/49c3646c158.html

United Nations Human Rights Council. (2009). Universal periodic review: Report of the working group on the universal periodic review: Bahamas (A/HRC/10/70). Retrieved from http://daccess-ddsny.un.org/doc/UNDOC/GEN/G09/100/90/PDF/ G0910090.pdf?OpenElement.

U. S. Department of State. (2009). Background note: Bahamas. Retrieved from http://www.state.gov/r/pa/ei/bgn/1857.htm

Walzer, M. (2008). The distribution of membership. In T. Pogge \& D. Moellendorf (Eds.), Global justice: Seminal essays (pp. 145177). St. Paul, MN: Paragon House. 